\title{
PLACE OF INFORMATION TECHNOLOGY IN THE PERFORMANCE OF MEDICAL ACTIVITIES
}

\author{
Sibilla Buletsa, \\ Head of the Department of Civil Law and Civil Procedure \\ of the Law Faculty of the Uzhgorod National University, \\ Doctor of Juridical Science, Full professor \\ ResearcherID: G-2664-2019 \\ orcid.org/0000-0001-9216-0033 \\ sibilla.buletsa@uzhnu.edu.ua
}

\section{Summary}

The state's policy is to integrate information systems into a single information space within the electronic health care system. The state plans and coordinates information systems that are implemented at the expense of the state or local budgets in order to rationalize the use of available resources and to avoid duplication of information systems functionality. With regard to information systems implemented through private funds, the function of the state is to build infrastructure (standardization, certification, market surveillance) for quality management in the market. The state provides single entry of information and its further processing in many information systems, storage of basic patient information within the central component of the WHO, and expanded information (eg data in clinical registers) in decentralized specialized information systems.

The purpose of this study is to study the place of information technology in the implementation of medical activities. I would point out that medical activity is a set of actions of medical and pharmaceutical workers in providing medical care or service to a patient within the legal (subject to obtaining a license) and ethical (oath of Hippocrates) norms, ie compliance with the stages of treatment in accordance with the established standards of the Ministry of Health. We used in research scientific methods to analise in an objective and systematic way the information technology in the performance of medical activities, describe it with empirical. formal-logical, comparative-legal methods.

It should be noted that e-Health is an electronic system that helps patients to receive and to doctors to provide quality medical services. All medical records throughout 2019 will be transmitted electronically. The main purpose of implementing an electronic healthcare system is to minimize fraud and corruption. In the future, e-Health will enable everyone to get their medical information quickly and doctors will be able to diagnose correctly with a holistic picture of the patient's health. The aim of the $\mathrm{MoH}$ is to launch a full-fledged eHealth by 2020 , which would not only reflect the relationship between the hospital and the state but also be a register of medical records of all Ukrainians.

Results. Thus, with the advancement of information technology, the growing share of medical research that relies on mathematical (computer) modelling has become commonplace in clinical practice, making it clear that IT capabilities are becoming a major contributor to medicine and health care. To date, many serious studies and projects are being implemented in the world to implement IT in the medical field. Due to medical reform, continuous computerization necessitated the need for medical staff to have computer skills. Today, in the medical field, services such as electronic medical record, electronic prescription, electronic referral, etc. are included in daily life. Electronic automated preparation of appointments, prescriptions, statements, hospital letters and other standardized documents 
for patients. In particular, there are automated databases of medical, pharmaceutical and scientific-pedagogical staff of the Ministry of Health of Ukraine.

Conclusion. The impact of IT on health care plays an extremely important role, as with the implementation of health care reform in Ukraine there is complete computerization of all branches of the medical field.

Key words: healthcare; patient; doctor; medicine; reforms; computer.

\section{Introduction}

Article 49 of the Constitution of Ukraine provides that everyone has the right to health care, medical assistance and health insurance. Health care is provided by state funding for relevant socio-economic, health and wellness programs. It should be emphasized that all medical activity is carried out in the field of medicine, that is, as noted by S.P. Botkin is a field of human knowledge that studies the person and nature that surrounds them, in their interaction to prevent disease, cure or alleviate the patient's condition.

However, it should be borne in mind that if F. Bacon set only three tasks for medicine: maintaining health, treating diseases, prolonging life, then in the modern literature indicates the five main directions of development of medicine: maintaining and maintaining the state of health, correction of normal and pathological life, regulation of life processes, management of human life and to some extent its design. Thus, a tendency is formed when the content of medical activity goes beyond the attainment of the highest level of physical and mental health (Solov'yev, 1999).

Medicine is a system of scientific knowledge aimed at disease prevention, treatment of patients, preservation and promotion of human health, life extension. The state and level of development of medicine the content and methods of medical activity depend on the material conditions of life, the general level of culture (Vasilenko, 1967). Therefore, medicine is a system of scientific knowledge and practical activity aimed at promoting and preserving health, extending human life, preventing and treating disease (Buletsa, 2015). The purpose of this study is to study the place of information technology in health care and to perform comparative analysis with individual countries.
It should be noted that medical activity can be governed by both private and public law. In particular, public law rules regulate organizational issues of medical activity, vertical relations with the participation of public health authorities, and state involvement in these relations also plays a lasting role, such as the procedure for licensing economic and legal entities in the field of health care or issues of epidemics, epizootics and more. It is noted that social relations in the private sphere (civil relations) are primary in relation to legal relations, as they may arise on the basis of the agreement of the parties, due to the actual actions of the participants in such relations, etc. The existence or absence of acts of civil law is not affected by the existence of civil relations (Kharytonov and Kharytonova, 2008).

Definition of the term medical activity in the legislation is regulated by the Fundamentals of the legislation of Ukraine on health care, other acts of the legislation on health care, normative-legal acts of the Ministry of Health of Ukraine (hereinafter - the Ministry of Health of Ukraine) activity on providing citizens with preventive care (Order of the Ministry of Health of Ukraine «On granting special permission for medical activity in the field of folk and non-traditional medicine», 2000). A necessary element of medical activity is admission to the exercise of medical activity. It is the object of the permit system. Such a right is granted by the state on the basis of a permit (license) and legal relations of public law arise.

Thus, medical activity is the set of actions of medical and pharmaceutical workers to provide medical care or services to a patient within the legal (subject to licensing) and ethical (Hippocratic oath) norms, ie compliance with the stages of treatment in accordance with the established standards of the Ministry of Health. paid or free (Buletsa, 2015). 
I note that modern information technology is increasingly used in medicine in connection with the implementation of medical reform. The level of informatization of the activity of public health institutions in Ukraine is increasing. Current trends in the global healthcare market are closely linked to the emerging capabilities of information technology. Today, there is an increasing number of healthcare facilities or medical centres that use medical information systems, electronic medical records, and generally electronic document circulation.

E-health is a term that, in the broadest sense, means the use of computer information technology for the purpose of improving the level of health, including the way in which health processes are thought and organized and related fields, including science, education, research. E-health is an industry and environment that includes not only information and telecommunication systems but also components such as governance, regulatory framework, standards and compliance control, human resources, infrastructure, strategy and investment model. It should be noted that e-Health is an electronic system that helps patients to receive and to doctors to provide quality medical services. e-Health enables everyone to get their medical information quickly, and for doctors to diagnose correctly with a holistic picture of the patient's health. The purpose of the $\mathrm{MoH}$ is to launch a full-fledged e-Health by the end of 2020, which would not only reflect the relationship between the hospital and the state but also be a register of medical records of all Ukrainians (Kolisnyk, 2017). eZdorovya is the main developer of eHealth technical core in Ukraine. eHealth is an electronic health care system that enables the exchange of health information and the implementation of the public health guarantee program. The eHealth system consists of: Central database - CBD (administrator of SE «EHealth») and electronic medical information systems - MIS (systems that allow automating the work of medical facilities with CBD). If in 2018, doctors signed declarations with patients through eHalth and patients signed up for admission, then in 2019, doctors would issue electronic hospital letters. The Cabinet of Ministers Resolution No. 328 (Resolution of the Cabinet of Ministers of Ukraine «Some Issues of Organizing the Electronic Register of Disability
Letters and Information Provision from it», 2019) of 17.04.2019 approved the Procedure for organizing the Electronic Register of Disability Sheets and provision of information. The purpose of the Registry is to ensure the accumulation, storage and use of information on issued, extended and accounted inoperative sheets, as well as to verify the validity of the issuance and continuation of incapacity sheets. The Register will be formed and maintained by the Pension Fund of Ukraine - the holder of the Register's data. MOH, NHS, PFU, FSF are subjects of information exchange. Information interaction will be conducted electronically in compliance with the requirements of the Laws of Ukraine (Law of Ukraine «On electronic trust services», 2017; "On the protection of information in information and telecommunication systems», 1994; "On protection of personal data", 2010). In the Registry, information about the insured person can be found by name, patronymic (if any) and date of birth of the insured person, his or her taxpayer's registration card registration number according to the principle of complete coincidence of all specified search identifiers and/or each of the specified search identifiers. Some of the information in the Register will be freely available. You will not need to be authenticated or authenticated to receive it. This is information about: number of the incapacity leaflet, date of its opening, continuation, closure, information on checking the validity of its issuance (if held); number, reasons, average duration of disability registered registers per month, quarter, year, by region, health care institutions, persons who have temporary disability; the number of unjustifiably issued and prolonged sheets of disability per month, quarter, year, by region, health care institutions, persons who have temporary disability; number of days of temporary disability per month, quarter, year, by region, insurer; amounts of allowances paid on the basis of disability sheets, per month, quarter, year, by insurers. This information will be impersonated. In this case, the employer will immediately receive information about the employee who went to the hospital. Instead of paper cards, there will be electronic cards to which doctors will enter all information about human health and the intended treatment. Also available in the electronic format will be prescriptions for the program «Available medicines». If a doctor prescribes a drug that is 
part of a state program, it will be given free of charge by electronic prescription at the pharmacy. Doctors will use electronic referrals to refer patients for additional examinations and to narrow specialists.

Thus, eHealth's electronic healthcare system involves working with patients: creating electronic medical records, recording a doctor's appointment, seeking free medical supplies at health facilities.

Health information systems. In Ukraine, there are, will be, improved and created various health information systems for different categories of users, which can be implemented in the state, communal or private ownership, have a centralized or decentralized structure. An example of such information systems is:

- information systems in health care facilities (dispensaries, hospitals, diagnostic centres, drugstores, etc.), which include - medical, hospital information systems, laboratory information systems, radiological, pharmacy information systems, teleconferencing systems, telemonitoring, planning systems and managing the resources of healthcare organizations;

- patient systems that provide access and management of medical data (patients' electronic offices, web portals, mobile applications, systems that carry medical data from wearables, etc.);

- emergency information systems;

- information systems for logistics management, inventory management of medicines and medical devices;

- information systems in the field of public health and epidemiological surveillance;

- registries and information systems in the field of transplantation;

- registries and systems related to the issuance of disability emails and certificates;

- clinical and population registers containing information on individual nosologies (for example, the National Cancer Registry, the register of patients requiring insulin therapy, etc.) (The concept of health informatization of Ukraine).

It is worth noting that the legal relations in this area are regulated by the Fundamentals of the legislation of Ukraine on health care, the Laws of Ukraine «On State Financial Guarantees of Medical Services for the Population" and «On Electronic Trust Services», by Decree of the Cabinet of Ministers of Ukraine dated 27.12.2017 No. 1101 «On the establishment of the National Health Service of Ukraine» and from 25.04.2018 №411 «Some Issues of the Electronic Health Care System», other normative legal acts.

It is the Decree of the Cabinet of Ministers of Ukraine dated April 25, 2018 No. 411 that approved the Procedure of functioning of the electronic health care system, which details the mechanism of functioning of the electronic health care system and its components, registration of users, entry and exchange of information and documents in electronic the health care system in accordance with the Law of Ukraine «On State Financial Guarantees of Public Health Services».

The functionality of the electronic healthcare system is very wide. In particular, patients will be able to register users in a central database, including the use of electronic identification; delineating the rights of users to make and view information in the central database, to make changes and additions to it; the ability to create, file, view and exchange medical selection declarations that provide primary care, prescriptions, referrals, medical records, other information and documents via electronic cabinets in accordance with user access rights; the possibility of concluding, amending and terminating contracts on public health services and contracts on reimbursement under the program of medical guarantees; creation and submission of electronic reports, primary, settlement and other contract documents through the central database, etc.

The electronic health system assumes the existence of a central database within which the following registers are maintained:

- Patient registry containing information about individuals who are entitled to guarantees under the Law of Ukraine "On State Financial Guarantees of Public Health Services»;

- Register of declarations of choice of the doctor providing primary care;

- Register of health business entities containing information on health care institutions, entrepreneurs licensed for medical practice, and laboratories that 
have concluded or intend to apply for health care contracting under a medical guarantee program or involving medical providers in the provision of medical services;

- A register of medical specialists containing information on persons who have received education in the field of health care;

- A register of health workers containing information on persons in employment with healthcare entities;

- Register of contracts on public health services, containing information on contracts on public health services under the program of medical guarantees, concluded with the NHSU;

- Register of reimbursement agreements containing information on reimbursement contracts under the medical guarantee program concluded with the NAAS.

Also, the electronic health system provides for compatibility and electronic interaction of the central database with other information systems and state information resources:

- Unified State Demographic Register;

- Unified State Register of Legal Entities, Individual Entrepreneurs and Public Formations;

- the State Register of Civil Status Acts;

- Unified state electronic database on education;

- the Unified State Register of the Ministry of Internal Affairs;

- other resources specified in the legal acts regulating the interaction of state electronic information resources (Dukhovna, 2019).

Specialists enter medical data, telemetry, and related information directly from medical equipment into computer databases during a real-time examination to further process, analyze, store, and maintain their access history. Electronic automated preparation of appointments, prescriptions, statements, hospital letters and other standardized documents for patients. In particular, there are automated databases of medical, pharmaceutical and scientific-pedagogical staff of the Ministry of Health of Ukraine (Order of the Ministry of Health of Ukraine "About formation of the automated database of medical, pharmaceutical and scientific-pedagogical workers of the sphere of management of the Ministry of Health of Ukraine», 2006).

The policy of the state is to integrate these information systems into a single information space within the framework of the WHO. The state plans and coordinates information systems that are implemented at the expense of the state or local budgets in order to rationalize the use of available resources and to avoid duplication of information systems functionality. With regard to information systems implemented through private funds, the function of the state is to build infrastructure (standardization, certification, market surveillance) for quality management in the market.

In Ukraine, the electronic health care system (hereinafter referred to as the ESOP) is a formulation of which is provided in the Law of Ukraine «On State Financial Guarantees of Public Health Services» (Law of Ukraine «On State Financial Guarantees of Public Health Services», 2017): an information and telecommunication system that provides automation of accounting of medical services and management of medical information through the creation, placement, publication and exchange of information, data and documents in electronic form, comprising a central database and electronic medical information systems, between which there is a matic exchange of information, data and documents through an open API. The electronic health care system includes a central database and electronic medical information systems, which provide for the automatic exchange of information, data and documents through an open software interface (API). The National Health Service of Ukraine (hereinafter referred to as NSAU) provides the functioning of the electronic health care system and the website containing information on the electronic health care system (hereinafter - the system website). The owner of the central database, including proprietary rights to the central database software, is the state represented by the NSA. The Ministry of Health is the manager of the Registry of Medical Specialists and the Register of Health Entities. The registry of other registers and the holder of their information and other information in the central database is the NSAU, unless otherwise specified by law. 
The central database is managed by the stateowned eHealth Enterprise (Resolution of the Cabinet of Ministers of Ukraine «Some Issues of the Electronic Healthcare System», 2018).

Advances in information, medical technology, clinical practice will inevitably lead to the development of new components and services, so the technical architecture of the POPs will not be static. Given the complexity of e-Health implementation and the speed of technological advancement, an important requirement for an architecture is its modularity and ability to flexibly respond to changing needs in the development of the EHP, and to scale it rapidly. Increasing cyber threats in the world, possible attacks on objects of information infrastructure of Ukraine, require special attention to the security, integrity and availability of data in the WHO.

When designing the structure, the POPs should take into account the autonomy of information systems in healthcare facilities, giving priority to continuous ways of exchanging data between systems. Electronic medical information systems may have the functionality of separate elements of the central component (registers, databases), to improve the stability of the system, provide access to data in the regions in conditions of insufficient speed of communication channels, reducing the risks of a single point of failure in the ESOP.

The principle of technological neutrality and independence from decision-makers should be taken into account in the development of the POPs. Existing communication channels (including wireless carriers) must be used to communicate. The exchange of data between ESOPs and other state information resources should be carried out mainly through the system of interaction of public electronic resources of Trembita, as well as other technical ways of interaction (Notification to the draft decree of the Cabinet of Ministers of Ukraine «On approval of the Health Informatization Concept of Ukraine», 2019).

The current level of development of specialized software for the work of physicians meets the highest standards of data security, located on the World Wide Web, which allows for on-line access to databases. Developments for patients were equally significant. Yes, today subscribers to speciality medical systems are able to get the help of a qualified health care practi- tioner practically 24 hours a day without leaving their homes. Since 2013, applications have been launched to ensure the seamless exchange of information between patients and physicians. The remote control technology provided to patients goes from experimentation and testing to implementation. This will allow hospitals to provide care by reducing the cost of rehospitalization, which often occurs in chronic conditions. The question of using popular mobile devices and mobile diagnostic devices is still relevant. Recent studies have shown that $91 \%$ of doctors are interested in using electronic medical records. In 2013, patients were given the opportunity to download vital monitoring applications such as heart rate and access to healthcare information applications on smartphones and tablets. In the near future, doctors and patients are considering using diagnostic devices on smartphones and tablets. Doctors will be able to provide assistance using their mobile devices, viewing cardio or encephalograms of the patient, laboratory test results, accepting documents, ordering the necessary medicines by e-prescription. The possibility of developing a number of medical programs for unhindered access to medical electronic cards is being actively considered. Mobile devices will be able to access data previously available only in clinics. Based on the results of research conducted by medical organizations, the following positive trends in the implementation of information technology in health care have been identified: improved treatment attitudes (the proportion of patients who actively use home self-control has increased); reducing the frequency of hospitalization of patients; reduction of mortality among patients compared to routine medical care technology; improving the quality of life, psychological and social status of patients; improving the level of satisfaction with the quality of medical services; raising patients' awareness of their disease; improvement of quality of service, timely correction of drug therapy, high efficiency of drug treatment; improving the cost-effectiveness of medical care. Today, to create the information technology of medicine, the future efforts of leading research teams are united and focused on developing new software architectures and programming languages; theoretical and methodological models of information processing; mathemat- 
ical methods for modelling complex biological systems; techniques for predicting a patient's possible response to a combination of drugs; algorithms for finding the optimal combination of therapies. This year, the healthcare IT market has reached $\$ 80$ billion, delivering an average annual 5\% growth rate over the next 5 years. Without a doubt, IT is a useful tool for improving the quality and effectiveness of care. However, their use requires a thorough approach to the training, management and management of medical personnel.

In order to remain competitive, IT companies need to be aware of government health information initiatives and the latest developments in the field of medicine, to take into account the requirements of electronic medical records, and to pay attention to the rapidly growing markets Asia and other developing regions.

The most relevant and popular technologies in the field of health care are electronic medical card, use of robotics in surgery, application of RFID technology.

Medical information system in Ukraine. In Ukraine, the healthcare system consists of a central component - it is responsible for the centralized storage and processing of information - and medical information systems (MIS) that hospitals and clinics can choose and market.

It should be noted that the Medical Information System (MIS) is a special type of software that aims at informing healthcare facilities and automating healthcare workflows. It creates a single information field for different levels of care delivery, from primary to tertiary level. In the latter case, all participants - primary care physicians, specialists, diagnosticians, inpatients, pharmacists, laboratory assistants and managers - work in a common information field, which enables to obtain all necessary information about the patient's health from one standardized source of information.

The components of the medical information system are ("Computerization does not stop», 2018):

1) an electronic medical record of the patient, or a special section on the patient, which stores personal, demographic and other useful information. In addition, all medical electronic records (doctor's findings, laboratory test results, diagnostic results, and other medical re- cords) are "attached» to the patient in the system through an electronic medical card;

2) accounting of the patient's requests for medical help to the medical-preventive institution. Usually, such records are implemented through the establishment of patient visit schedules, physicians' schedules and other medical resources of the medical facility. There are special sections of MIS, such as "Registry" or "Polyclinic», to deal with the patient's appeals. It should be noted that the movement of patients depends on the profile of the medical institution. Thus, if a doctor needs to arrange an outpatient clinic for patients, then the module «Registry" should be used, and if the institution has an inpatient type of medical care, then the module «Reception unit» or "inpatient» is required. Accordingly, each module or section of the IIA performs certain tasks that are specific to the organization of outpatient and inpatient care;

3) Medical records in MIS - is a key section that documents electronically all the actions of medical professionals, the results of diagnostics, laboratory tests, internal medical records and other documents. MIS should be adapted to the regulatory and accounting policies of the Ministry of Health of Ukraine and directly to the medical institution where the information system is applied;

4) records of medicines and medical supplies - this section of the IIA provides an opportunity to account for the movement and use of medicinal products and medical supplies through appropriate medical documents: doctor's recommendations for treatment (in case of outpatient admission) and prescription (including electronic) and a letter of medical prescriptions (in the case of inpatient treatment);

5) directories and registers. Modern MIS is a tool for standardizing and collecting information on the quality of care. Accordingly, standardization, as a task that MIS helps to perform to healthcare professionals, is an important feature of modern MIS. Yes, the MIS should include key directories: MKH-10, medicines directory, patient status guides, temporary industry classifier of medical procedures (services) and surgeries. And now for the primary care doctors and guide ICPC-2 Ukraine.

Experience of European countries in the introduction of IT in medicine. It should be not- 
ed that IT has already been deployed in Europe since 2009, for example, over 600 terminals with 17 monitors have appeared at the Annecy central hospital in eastern France, allowing hospital staff to view electronic medical records. about patients is done with the help of personal badges. After identification, doctors can familiarize themselves with appointments, make adjustments in them. The prescribed medication immediately passes a test for compatibility with already prescribed drugs and on the answer, The prescribed medication data are automatically sent to the pharmacy from where the drugs are delivered to the patient's ward while being one of the largest in France's Le Mans central hospital (more than 1600 beds, 60,000 patients per year, 400 doctors and more 4,000 other health care providers) implemented a medical information system and switched to electronic patient medical records.

The UK has launched one of the largest IT industries in the history of creating a network of 30,000 computers installed in 300 medical facilities in the country, with hard drives containing information about 50 million patients.

A new Stobhill hospital has been opened in Scotland, capable of serving more than 400,000 patients a year. The peculiarity of this hospital is that it is absolutely paperless - it incorporates a system of electronic medical records and uses portal technologies that allow doctors to access patient data at any time.

An electronic medical history has been implemented at the emergency rooms of Lisboa Norte Hospital Complex, a medical centre serving the St. Mary's Hospital in Lisbon and the Hospital of the district of Sant Antonio du Cavaleiro, which is located in the municipality of Loures, near the capital of Portugal. The St. Mary's Hospital has been using electronic case histories for three years, and the hospital in Loures moved to them only in November 2009.

Hospital de Denia in Spain (Valencia) in 2009 switched to the industrial operation of the medical information system, the implementation of which took almost a year and a half. At the moment, the hospital automates the activities of the departments of ambulance, surgery and radiology, patient flow management, processing of information about the results of analyzes, ordering medicines, scheduling work of doctors and nurs- es, maintaining medical records. Hospital doctors work with electronic medical records and from their workplace receive information from devices near the patient's bed - monitors, fans, etc. The hospital's medical information system is linked to the information systems of the regional government and other health care institutions.

At the same time, telemedicine services have become available throughout Andalusia. In Malaga and Seville, there are 99 and 55 operator stations respectively. The total number of user calls received in 2009 exceeded 3 million. The topics of these calls range from general medical information and pharmacy information to remote consultation with a specialist.

For example, the goals of the Chinese government's policy at the National Health Summit in January 2019 are realistic and commendable. They focus on such important areas as the promotion of integrated delivery systems, including enhancing the capacity of public hospitals at county level to facilitate care coordination and referral, primary care for family physicians, telemedicine, central procurement of essential medicines to increase cost efficiency, and review of prices for medical services and fees, etc. These reforms, if successfully implemented in close collaboration with stakeholders, including the private sector, will pave the way for a sustainable health care system for China in the coming years (Cheng, 2019).

The Hungarian Government Decree «Government Decree 1798/2019 (XII. 23.) on certain health issues» was adopted on 23 December 2019 and was issued on 25 December, which prepares for major changes in the health sector by 2020 (Sandor, 2020). The government's decision made it clear that the system would be new. The goal is to start off real costs. So far, government decisions have only set goals and timelines for restructuring by 2020 , or at least start the work needed to fund health care. The overriding objective is to restructure the financing system and the supply structure, "which leads to a sustainable functioning and prevents debt rebirth». There are eight points of health care reform and two points to address the serious debt of healthcare facilities. Mention has been made of the development of telemedicine and the increased use of innovative technologies to simplify the organization of care (Gergely, 2019). 


\section{Conclusions}

Therefore, due to medical reform, continuous computerization has necessitated the need for medical staff to have computer skills. Today, in the medical field, services such as electronic medical record, electronic prescription, electronic referral, etc. are included in daily life. Thus, the impact of IT on health care plays an extremely important role, as with the implementation of health care reform in Ukraine there is complete computerization of all branches of the medical field.

Thus, the impact of IT on health care plays an extremely important role, since with the implementation of health care reform in Ukraine there is a complete computerization of all branches of the medical field, the issue of financing health care institutions for the introduction of new technologies remains unresolved. With the advancement of information technology, the growing share of medical research that relies on mathematical (computer) modelling has become commonplace in clinical practice, making it clear that IT capabilities are becoming a major contributor to medicine and healthcare. To date, many serious studies and projects are being implemented in the world to implement IT in the medical field. Financing of health informatization begins. By turning digital data into knowledge, doctors can more reasonably apply it. Health information technology is a vital industry that needs to provide effective, safe and reliable healthcare. And this industry is developing most dynamically. IT is now being used at all stages of health care, from basic research to healthcare delivery, and includes a number of specializations, such as bioinformatics, clinical informatics and biomedical informatics. The electronic medical card is in full swing, SMS informing about the results of the tests taken in the laboratory with their subsequent review in the laboratory information system, remote fixation and translation of physiological parameters, computer simulation of complex biological processes, 3-D modelling of tissues and organs, objective evaluation in solving problems of diagnostics, interpretation of data, prediction of the course of diseases and complications, monitoring of the course of diseases and planning of medical diagnostics ary process. Automated workplaces of doctors allow optimizing various processes of medical activity, making it more efficient. With the help of the Internet, health care providers have access to the latest up-to-date health care information and can establish professional relationships with foreign colleagues to share experiences. An important positive trend in the introduction of information technology into medicine is the ability to interact with external sources of information through on-line conferences, which allows leaving the patient to solve complex issues with the help of more experienced colleagues.

Due to medical reform, continuous computerization necessitated the need for medical staff to have computer skills. Today, in the medical field, services such as electronic medical record, electronic prescription, electronic referral, etc. are included in daily life. Specialists enter medical data, telemetry, and related information directly from medical equipment into computer databases during a real-time examination to further process, analyze, store, and maintain their access history. Electronic automated preparation of appointments, prescriptions, statements, hospital letters and other standardized documents for patients. In particular, there are automated databases of medical, pharmaceutical and scientific-pedagogical staff of the Ministry of Health of Ukraine.

\section{Bibliography:}

1. Колісник Т. Чи врятує вітчизняну медицину е-Health? Baше здоров'я. 2017. URL: http://www.vz.kiev.ua/chyvryatuye-vitchyznyanu-medytsynu-e-health/ (дата звернення: 20.02.2020).

2. Соловьев В.Н. Гражданско-правовое регулирование отношений, возникающих при реализации конституционного права граждан на медицинскую помощь : автореф. дис. на соискание учен. степени канд. юрид. наук: 12.00.03. Томск, 1999. 30 с.

3. Малая медицинская энциклопедия в 12-ти т. / отв. ред. В.Х. Василенко; АМН СССР. Москва : «Советская энциклопедия», 1967. Т. 5: Ларусан-Молоко. 1167 с.

4. Булеца С.Б. Цивільно-правові відносини в галузі медичної діяльності: проблеми теорії та практики : монографія. Ужгород: Поліграфцентр «Ліра», 2015.600 с.

5. Харитонов Є.О., Харитонова О.І. Цивільні правовідносини: навч. посіб. Київ : Істина, 2008. 304 с.

6. Про надання спеціального дозволу на медичну діяльність у галузі народної і нетрадиційної медицини: Наказ Міністерства охорони здоров’я України від 
10.08.2000 р. № 195. Офіщійний вісник України. 2001. № 9. Ст. 328.

7. Деякі питання організації ведення Електронного реєстру листків непрацездатності та надання інформації з нього: Постанова Кабінету Міністрів України від 17.04.2019 р. № 328. Офіційний вісник України. 2019. № 34. СТ. 1210.

8. Про електронні довірчі послуги: Закон України від 05.10.2017 р. № 2155-VIII. Офіційний вісник України. 2017. № 91. Ст. 2764.

9. Про захист інформації в інформаційно-телекомунікаційних системах: Закон України від 05.07.1994 р. № 80/94-ВР. Відомості Верховної ради України. 1994. № 32. СТ. 286.

10. Про захист персональних даних: Закон України від 01.06.2010 р. № 2297-VI. Голос України. 2010. № 172.

11. Концепція інформатизації охорони здоров'я України. URL: https://moz.gov.ua/uploads/2/12639pro_20190604_1_dod.pdf (дата звернення: 20.02.2020).

12. Духовна О.Продовження медичної реформи:що зміниться у 2019 році? Юридична газета. 2019.№ 6(660). URL: https://yur-gazeta.com/publications/practice/ medichne-pravo-farmacevtika/prodovzhennyamedichnoyi-reformi-shcho-zminitsya-u-2019-roci. html (дата звернення: 20.02.2020).

13. Про формування автоматизованої бази даних медичних, фармацевтичних та науково-педагогічних працівників сфери управління МОЗ України: Наказ Міністерства охорони здоров'я України від 19.12.2006 p. № 842. Офіційний вісник України. 2007. № 5. Ст. 185.

14. Про державні фінансові гарантії медичного обслуговування населення: Закон України від 19.10.2017 р. № 2168-VIII. Голос України. 2017. № 248.

15. Деякі питання електронної системи охорони здоров'я: Постанова Кабінету Міністрів України від 25.04.2018 р. № 411. Офіційний вісник України. 2018. № 46. Ст. 1604.

16. Повідомлення до проекту розпорядження Кабінету Міністрів України «Про схвалення Концепції інформатизації охорони здоров’я України». Аnтека online. 2019. URL: https://www.apteka.ua/article/503988 (дата звернення: 20.02.2020).

17. Комп'ютеризація не зупиняється. Практика управління медичним закладом. 2018. URL: http://med-info.net. ua/index.php?q=content/kompyuterizats\%D1\%96yane-zupinya\%D1\%94tsya (дата звернення: 20.02.2020).

18. Cheng T-M. Between a rock and a hard place: China's health care reforms over the next ten years. Asia Dialogue. 2019. URL: https://theasiadialogue. com/2019/03/27/between-a-rock-and-a-hard-placechinas-health-care-reforms-over-the-next-ten-years/ (дата звернення: 20.02.2020).
19. Sándor J. A karácsonyfa alá rejtette a kormány az egészségügyi reformját? Index. 2020. URL: https:// index.hu/belfold/2020/01/01/korhaz_egeszsegugy_ finanszirozas_kormanyhatarozat_atalakitas_sinko_ eszter/ (дата звернення: 20.02.2020).

20. Gergely C. Alapjaiban forgatná fel a magyar egészségügyet az MNB javaslata. Portfolio. 2019. URL: https://www.portfolio.hu/gazdasag/20190228/ alapjaiban-forgatna-fel-a-magyar-egeszsegugyet-azmnb-javaslata-315763 (дата звернення: 20.02.2020).

\section{References:}

1. Kolisnyk, T. (2017). Chy vryatuye vitchyznyanu medytsynu e-Health? Vashe zdorov'ya [Will domestic medicine save e-Health? Your health]. Retrieved from http://www.vz.kiev.ua/chy-vryatuye-vitchyznyanumedytsynu-e-health/ [in Ukraine].

2. Solov'yev, V.N. (1999). Grazhdansko-pravovoye regulirovaniye otnosheniy, voznikayushchikh pri realizatsii konstitutsionnogo prava grazhdan na meditsinskuyu pomoshch' [Civil regulation of relations arising in the exercise of the constitutional right of citizens to medical care]. Dissertatsiya candidata yuridicheskikh nauk: 12.00.03 [PhD]. Tomsk. [in Russia].

3. Vasilenko, V.KH. (1967). Malaya meditsinskaya entsiklopediya $\vee$ 12-ti tomakh. T. 5: Larusan-Moloko [Small medical encyclopedia in 12 volumes. V. 5: Larusan-Milk]. Moskow: Sovetskaya entsiklopediya. [in Russia].

4. Buletsa, S.B. (2015). Tsyvil'no-pravovi vidnosyny v haluzi medychnoyi diyal'nosti: problemy teoriyi ta praktyky [Civil-legal relationships in the galaxy of medical care: problems and theory of practice]. Uzhhorod: Lira. [in Ukraine].

5. Kharytonov, YE.O., Kharytonova, O.I. (2008). Tsyvil'ni pravovidnosyny [Civil Relations]. Kyyiv: Istyna. [in Ukraine].

6. Pro nadannya spetsial'noho dozvolu na medychnu diyal'nist' u haluzi narodnoyi i netradytsiynoyi medytsyny (2000). Nakaz Ministerstva okhorony zdorov'ya Ukrayiny [On granting special permission for medical activity in the field of folk and non-traditional medicine. Order of the Ministry of Health of Ukraine]. Ofitsiynyy visnyk Ukrayiny, no. 9, 288 p.

7. Deyaki pytannya orhanizatsiyi vedennya Elektronnoho reyestru lystkiv nepratsezdatnosti ta nadannya informatsiyi z n'oho (2019). Postanova Kabinetu Ministriv Ukrayiny [Some Issues of Organizing the Electronic Register of Disability Letters and Information Provision from it. Resolution of the Cabinet of Ministers of Ukraine]. Ofitsiynyy visnyk Ukrayiny, no. 34, 274 p. 
8. Pro elektronni dovirchi posluhy (2017). Zakon Ukrayiny No. 2155-VIII [On electronic trust services. Law of Ukraine No. 2155-VIII]. Ofitsiynyy visnyk Ukrayiny, no. 91, 5 p.

9. Pro zakhyst informatsiyi $v$ informatsiyno-telekomunikatsiynykh systemakh (1994). Zakon Ukrayiny No. 80/94-VR [On the protection of information in information and telecommunication systems. Law of Ukraine No. 80/94-VR]. Holos Ukrayiny.

10. Pro zakhyst personal'nykh danykh (2010). Zakon Ukrayiny No. 2297-VI [On protection of personal data. Law of Ukraine No. 2297-VI]. Holos Ukrayiny, no. 172.

11. Kontseptsiya informatyzatsiyi okhorony zdorov'ya Ukrayiny [The concept of health informatization of Ukraine]. Retrieved from https://moz.gov. ua/uploads/2/12639-pro_20190604_1_dod.pdf [in Ukraine].

12. Dukhovna, O. (2019). Prodovzhennya medychnoyi reformy: shcho zminyt'sya u 2019 rotsi? [Continuing medical reform: what will change in 2019?]. Yurydychna hazeta, no. 6 (660). Retrieved from https://yurgazeta.com/publications/practice/medichne-pravofarmacevtika/prodovzhennya-medichnoyi-reformishcho-zminitsya-u-2019-roci.html [in Ukraine].

13. Pro formuvannya avtomatyzovanoyi bazy danykh medychnykh, farmatsevtychnykh ta naukovo-pedahohichnykh pratsivnykiv sfery upravlinnya MOZ Ukrayiny (2006). Nakaz Ministerstva okhorony zdorov’ya Ukrayiny [About formation of the automated database of medical, pharmaceutical and scientific-pedagogical workers of the sphere of management of the Ministry of Health of Ukraine. Order of the Ministry of Health of Ukraine]. Ofitsiynyy visnyk Ukrayiny, no. 5, 41 p.

14. Pro derzhavni finansovi harantiyi medychnoho obsluhovuvannya naselennya (2017). Zakon Ukrayiny No. 2168-VIII [On State Financial Guarantees of Public Health Services. Law of Ukraine No. 2168-VIII]. Voice of Ukraine, no. 248.
15. Deyaki pytannya elektronnoyi systemy okhorony zdorov'ya (2018). Postanova Kabinetu Ministriv Ukrayiny [Some Issues of the Electronic Healthcare System: Resolution of the Cabinet of Ministers of Ukraine]. Ofitsiynyy visnyk Ukrayiny, no. 46, 14 p.

16. Povidomlennya do proektu rozporyadzhennya Kabinetu Ministriv Ukrayiny «Pro skhvalennya Kontseptsiyi informatyzatsiyi okhorony zdorov'ya Ukrayiny» (2019). [Notification to the draft decree of the Cabinet of Ministers of Ukraine «On approval of the Health Informatization Concept of Ukraine»]. Apteka online. Retrieved from https://www.apteka.ua/article/503988 [in Ukraine].

17. Komp'yuteryzatsiya ne zupynyayet'sya (2018). [Computerization does not stop]. Praktyka upravlinnya medychnym zakladom. Retrieved from http://med-info.net.ua/index.php?q=content/ kompyuterizats\%D1\%96ya-ne-zupinya\%D1\%94tsya [in Ukraine].

18. Cheng, T-M. (2019). Between a rock and a hard place: China's health care reforms over the next ten years. Asia Dialogue. Retrieved from https://theasiadialogue. com/2019/03/27/between-a-rock-and-a-hard-placechinas-health-care-reforms-over-the-next-ten-years/

19. Sandor, J. (2020). A karachon'fa ala reytette a korman' az egeshzhegyud'i reform'yat? [Has the government concealed health reform under the Christmas tree?]. Index. Retrieved from https://index. hu/belfold/2020/01/01/korhaz_egeszsegugy_ finanszirozas_kormanyhatarozat_atalakitas_sinko_ eszter/ [in Hungarian].

20. Gergely, C. (2019). Alap'yaiban forgatna fel' a mad'yar egeshzhegyud'yet az MNB yavashlata [The proposal of the MNB would revolutionize Hungarian health care fundamentally]. Portfolio. Retrieved from https:// www.portfolio.hu/gazdasag/20190228/alapjaibanforgatna-fel-a-magyar-egeszsegugyet-az-mnbjavaslata-315763 [in Hungarian].

\section{МІСЦЕ ІНФОРМАЦІЙНИХ ТЕХНОЛОГІЙ ПРИ ЗДІЙСНЕННІ МЕДИЧНОЇ ДІЯЛЬНОСТІ}

\section{Сібілла Булеца,}

Доктор юридичних наук (доктор Хабіл), професор, Завідувач кафедри цивільного права та иивільного процесу, Юридичного факультету Ужгородського національного університету, Голова Асоціації цивілістів в Закарпатської області ORCID: https://orcid.org/0000-0001-9216-0033, 
sibilla.buletsa@uzhnu.edu.ua,

https://www.uzhnu.edu.ua/uk/cat/flaw-urcivil

Ідентифікатор дослідника: G-2664-2019

\section{Резюме}

Політика держави полягає у інтеграції інформаційних систем в єдиний інформаційний простір в рамках електронної системи охорони здоров'я. Держава планує та координує інформаційні системи, які впроваджуються за рахунок державного або місцевих бюджетів з метою раціоналізаторського використання наявних ресурсів та уникнення дублювання функціональності інформаційних систем. Стосовно інформаційних систем, що реалізуються за рахунок приватних фондів, функція держави полягає у побудові інфраструктури (стандартизація, сертифікація, нагляд за ринком) для управління якістю на ринку. Держава забезпечує одноразове введення інформації та їі подальшу обробку у багатьох інформаційних системах, зберігання основної інформації про пацієнтів у центральній складовій частині ВООз та розширену інформацію (наприклад, дані у клінічних реєстрах) у децентралізованих спеціалізованих інформачійних системах.

Метою даного дослідження $\epsilon$ дослідження місия інформаційних технологій при здійсненні медичної діяльності. Слід зазначити, що медична діяльність - це сукупність дій медичних та фармацевтичних працівників щодо надання медичної допомоги або послуги пацієнту в рамках правових (за умови отримання ліцензіі) та етичних (клятва Гіппократа) норм, тобто дотримання етапів лікування відповідно до встановлених стандартів МO3.

В дослідженні використовувалися наукові методи для об'єктивного та систематичного аналізу інформаційних технологій при виконанні медичної діяльності, а саме емпіричний, формально-логічний, порівняльно-правовий методи.

Слід зазначити, що е-Неalth - це електронна система, яка допомагає отримувати пацієнтам, а лікарям надавати якісні медичні послуги. Усі медичні записи протягом 2019 року будуть передаватися в електронному вигляді. Основною метою впровадження електронної системи охорони здоров'я є мінімізація шахрайства та корупиії. У майбутньому е-Неalth дозволить кожному швидко отримати свою медичну інформацію, а лікарі зможуть правильно поставити діагноз із цілісною картиною стану здоров'я пацієнта. Метою МОз $\epsilon$ запуск повноцінного електронного охорони здоров'я до 2020 року, який не лише відображатиме стосунки між лікарнею та державою, а й буде реєстром медичних карток усіх українців.

Результати. Таким чином, із розвитком інформаційних технологій, зростаюча частка медичних досліджень, що спираються на математичне (компютерне) моделювання, стала звичним явищем у клінічній практиці, даючи зрозуміти, що ІТ-можливості стають основним фактором, що сприяє медицині та охороні здоровя. На сьогоднішній день у світі впроваджується багато серйозних досліджень та проектів для впровадження ITу медичній галузі. Завдяки медичній реформі, безперервна компютеризація викликала необхідність у медичному персоналі володіти комп'ютерними навичками. Сьогодні в медичній галузі такі послуги, як електронна медична карта, електронний рецепт, електронне направлення тощо, включені в повсякденне життя. Електронна автоматизована підготовка призначень, рецептів, заяв, листів до лікарні та інших стандартизованих документів для пацієнтів. Зокрема, існують автоматизовані бази даних медичних, фармацевтичних та науково-педагогічних працівників МОЗ України.

Висновок. Вплив IT на охорону здоров'я відіграє надзвичайно важливу роль, оскільки із впровадженням реформи охорони здоров'я в Україні відбувається повна комп'ютеризація всіх галузей медичної галузі.

Ключові слова: охорона здоров'я, пачієнт, лікар, медицина, реформи, компютер, інформаційні технології. 